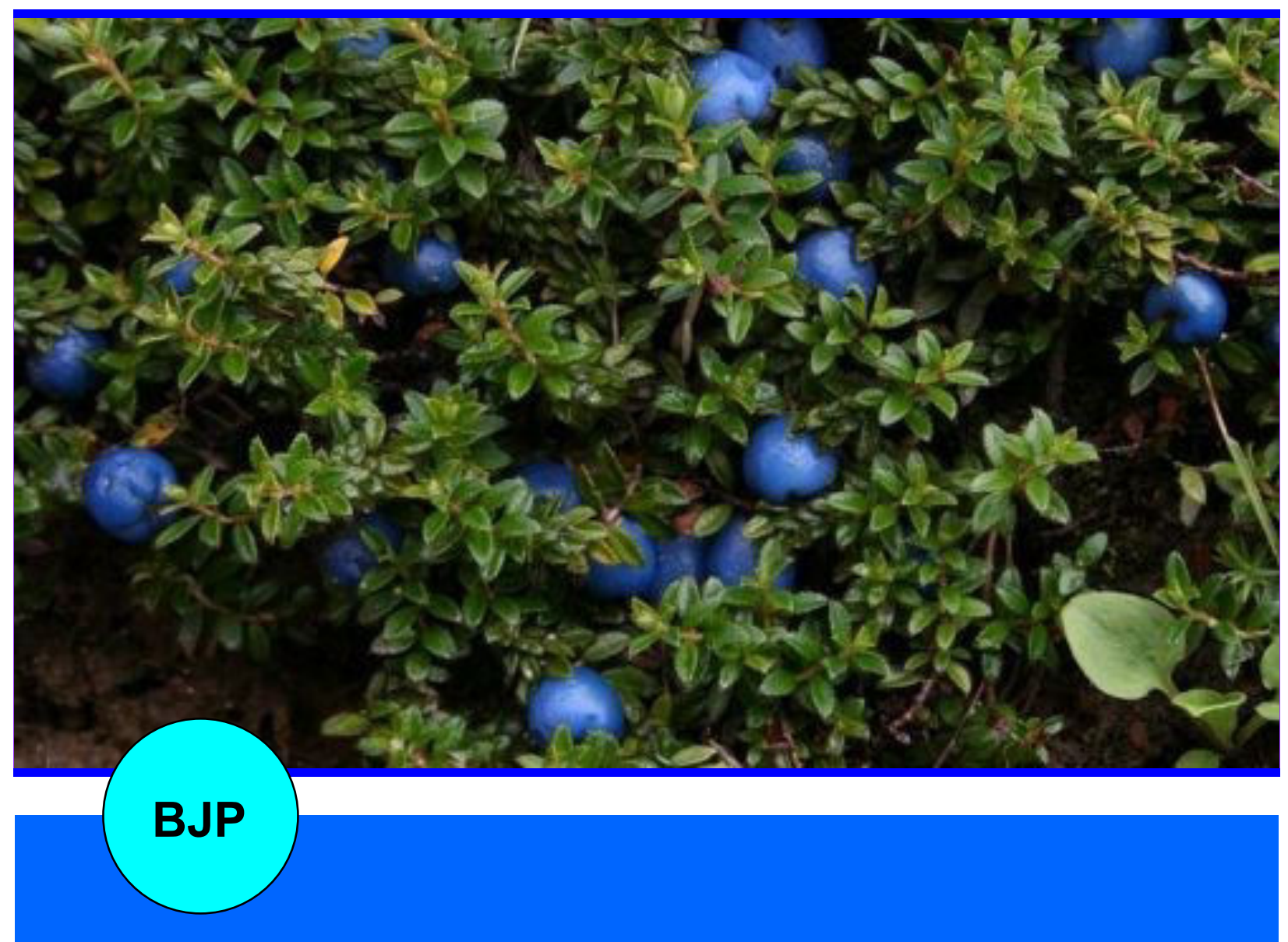

Bangladesh Journal of Pharmacology

Research Article

Effect of crude saponins from Gaul-
theria trichophylla extract on
growth inhibition in human colorec-
tal cancer cells 


\title{
Effect of crude saponins from Gaultheria trichophylla extract on growth inhibition in human colorectal cancer cells
}

\author{
Fiaz Alam', Qazi Najumus Saqib and Abdul Waheed² \\ ${ }^{1}$ Department of Pharmacy, COMSATS Institute of Information Technology, Abbottabad, Pakistan; ${ }^{2}$ Wolfson Cell \\ Science Centre, Faculty of Health \& Medical Sciences, University of Surrey, Guildford, UK.
}

\begin{tabular}{|c|c|}
\hline \multicolumn{2}{|l|}{ Article Info } \\
\hline Received: & 5 January 2015 \\
\hline Accepted: & 31 January 2015 \\
\hline Available Online: & 1 March 2015 \\
\hline \multicolumn{2}{|c|}{ DOI: 10.3329/bjp.v10i1.21462 } \\
\hline \multicolumn{2}{|c|}{$\begin{array}{l}\text { Cite this article: } \\
\text { Alam F, Saqib QN, Waheed A. Effect } \\
\text { of crude saponins from Gaultheria } \\
\text { trichophylla extract on growth inhibi- } \\
\text { tion in human colorectal cancer cells. } \\
\text { Bangladesh J Pharmacol. 2015; } 10: 160 \\
-65 \text {. }\end{array}$} \\
\hline
\end{tabular}

\section{Abstract}

The genus Gaultheria also comprised of species with reported cytotoxic activities. Current research work was carried out to evaluate G. trichophylla crude extract and respective saponins fraction against human colorectal cancer cell line (Caco-2) based on cell viability assays. Caco-2 cells treated with the crude extract showed significant growth inhibition $(\mathrm{p}<0.001)$ in a dose dependent manner with apparent $\mathrm{IC}_{50}$ value of $200 \mu \mathrm{g} / \mathrm{mL}$ and $100 \mu \mathrm{g} /$ $\mathrm{mL}$ in MTT and NRU assays respectively. The fractioned crude saponins showed an enhanced response and inhibited the growth of Caco- 2 by 93.6 and $97.4 \%$ in MTT and NRU assays respectively, with compared to actinomycin-D $(65 \%)$. The DAPI staining of cell treated with crude saponins observed under confocal microscope showed shrunken nuclei with apparent nuclear fragmentation and chromatin condensation indicating apoptosis mode of cell death. The study exhibited that the G. Trichophylla saponins induced apoptosis of Caco-2 cell lines. This study provides new evidences to further explore this plant for the novel targets in anticancer drug development.

\section{Introduction}

Colorectal cancer is the third most common malignant neoplasm worldwide and has become one of the major causes of cancer mortality (Siegel et al. , 2013). Several studies revealed that loss of control of apoptosis results in initiation of cancer and therefore, many new treatment procedures targeting apoptosis are feasible and may be used to treat various types of cancers (Wong, 2011).

It is well known that in the past some medicinally important plants like Catharanthus roseus, Podophyllum peltatum and Taxus brevifolia and others provided therapeutically active metabolites which were used to control the advance stages of malignancies (Farnsworth and Soejarto, 1991). However, most of these chemotherapeutic agents showed untoward effects like mutagenicity and teratogenicity. Therefore, as always, there is need to find alternative drugs with low toxicity, more effective and accessible to common man.

The present study was carried out to investigate the anticancer activity of crude extract and respective saponins fraction of Gaultheria trichophylla in cultured human colorectal cancer cells (Caco-2).

G. trichophylla belongs to family Ericaceae which consists of 90 genera and over 1,700 species. It is native to Himalayas and commonly known as Himalayan snowberry (Huang, 2003). The flowers range in colour from red, to pink; fruits are blue-coloured berries; and small green leaves are approximately 3-7 $\mathrm{mm}$ in length. This plant is an inhabitant of cold and lofty locations of the mountains and like many plants of such locations, it is furnished with setae. The calyx is adherent to the lower part of the capsule, becomes succulent, and forms an edible fruit in the 
month of September (Royle, 1839). In China, India, USA and Canada, G. yunnanensis, G. fragrantissima and G. procumbens are used in traditional medicine to treat arthritis (Liu et al., 2013; Simon et al., 1984). Research work on other species of this plant indicates that it has anti-inflammatory (Zhang et al., 2011), antibacterial (Cybulska et al., 2011) and antiarthritis activities (Xiong et al., 2009). The plants of this genus including G. itoana Hayata and G. yunnanensis are reported to possess cytotoxic activities against the selected cancer cell lines (Chen et al., 2009; Li et al., 2010). Gaultherin a natural salicylate isolated from G. yunnanensis possess analgesic and anti-inflammatory activity (Zhang et al., 2006). The phytochemical investigation of species investigated reported to contain methyl salicylate, diterpenoids, acids, dilactone, alkaloids and other glycosides (Alauddin et al., 1965; Cambie et al., 1961; El-Basyouni et al., 1964; Grisebach and Vollmer, 1964; Ibrahim and Towers, 1960; Zhang et al., 1999; Zhang et al., 1998).

\section{Materials and Methods}

\section{Chemicals}

The Caco-2 (human colon adenocarcinoma) cell line was obtained from the ECCC (European Collection of Cell Cultures) through Health Protection Agency, Salisbury, UK (Catalogue No. 86010202). Neutral red solution, fetal bovine serum (FBS), actinomycin-D, Dulbecco's modified Eagle medium (DMEM) and 4,6diamidineo-2-phenylinldole (DAPI) were obtained from Sigma Chemical Co. (St Lois, MO, USA).

\section{Plant material}

G. trichophylla plant $(5 \mathrm{~kg})$ was collected from Kaghan valley, District Mansehra, KPK, Pakistan, in November, 2013. After authentication of the plant, its voucher specimen (CTPHM-GT01, 13) was deposited in the herbarium of the department of pharmacy, COMSATS institute of information technology Abbottabad. The whole plant was washed under running water and dried in shade at room temperature and was ground to a coarse powder. The powder drug was stored in air tight and light resistant container before extraction.

\section{Preparation of extract and crude saponins}

The dried powdered plant material (200 g) was extracted with methanol using soxhlet extractor for 20 hours. It was filtered through a Whatman Grade-I filter paper. The filtrate was evaporated on a vacuum rotary evaporator under reduced pressure at $40^{\circ} \mathrm{C}$. Extracted percent yield of the methanol fraction was $21.9 \%$.

Extraction of saponins from powdered materials (200 g) of whole plant of G. trichophylla was done first with petroleum ether, followed by extraction with methanol in Soxhlet apparatus. The solvent was reduced on rotary evaporator under vacuum to obtain dry semi solid extracts. The methanol extract of the plant was further fractionated with n-butanol and water, in equal proportion. The n-butanol fraction was separated. The crude saponins were precipitated with petroleum ether, yield was approximately $4.5 \mathrm{~g}$ of crude saponin extract (Dande et al., 2010).

\section{Cell culture}

Caco-2 Cells were grown in complete growth medium: Dulbecco's modified Eagle medium (DMEM) containing $10 \% \mathrm{v} / \mathrm{v}$ FBS, $2 \mathrm{mM}$ L-glutamine, gentamycin $(40 \mu \mathrm{g} / \mathrm{mL})$, penicillin $(100$ units $/ \mathrm{mL})$ and streptomycin $(1,040 \mu \mathrm{g} / \mathrm{mL})$. When cells were in a logarithmic phase of growth during passages, cells were seeded into 96-well cell culture plates at a density of $1 \times 10^{4}$ cells per well in $100 \mu \mathrm{L}$ aliquots of medium. The cells were allowed to incubate for 24 hours at $37^{\circ} \mathrm{C}$, $5 \% \mathrm{CO}_{2}$ in air in a humidified atmosphere.

\section{Preparation of test samples for the experiment}

Crude extract of the medicinal plant G. trichophylla was tested for cell cytotoxicity against cancer cell line Caco2. A series of eight dilutions (10, 25, 50, 100, 200, 300, 400 and $500 \mu \mathrm{g}$ of final concentration) of plant crude extract were prepared in DMEM $(100 \mu \mathrm{L})$ containing DMSO (dimethyl sulfoxide, maximum: 0.01\%). After the preliminary screening results a test dose of $200 \mu \mathrm{g}$ for MTT assay and $100 \mu \mathrm{g}$ for neutral red uptake assay was set for saponins extract based on apparent $\mathrm{IC}_{50}$ of methanol extract.

\section{Cytotoxicity assays}

After a 24 hours exposure test period, the toxic endpoints were determined using two colorimetric assays; namely the methyl-thiazolyl-tertrazolium (MTT) assay and neutral red uptake assay.

\section{MTT assay}

Mitochondria are the cell's main energy producers and are therefore essential for cellular life, however, recent research has shown that these organelles play a key role in cell death when their membranes become permeable (Green and Kroemer, 2004). The MTT assay measures the mitochondrial function activity of mitochondrial dehydrogenases. MTT is a yellow colored dye [3-(4,5dimethyl- 2- thiazolyl)-2,5-diphenyl-2H-tetrazolium bromide], which converts to a purple insoluble product formazan as a result of reduction reaction with concomitant oxidation of NADH (nicotinamide adenine dinucleotide-reduced) and NADPH (nicotinamide adenine dinucleotide phosphate-reduced) through the ability of the mitochondrial succinic dehydrogenase enzyme in living cells (Twentyman and Luscombe, 1987).

According to the method described by (Borenfreund et al., 1988) growth of cancer cells was quantified. Following a 24 hours exposure test period of drugs, 
cells were washed twice with phosphate buffer saline (PBS), and a $10 \mu \mathrm{L}$ of MTT reagent $(5 \mathrm{mg} / \mathrm{mL}$ in PBS) was added to each well including the blanks, which contained medium only. The plates were returned to the incubator for 4 hours at $37^{\circ} \mathrm{C}$. Subsequently, cells were washed twice with PBS, and $100 \mu \mathrm{L} /$ well DMSO was added in each well as solvent to dissolve the insoluble crystalline formazan products. The effect of plant extracts on cancer cells was quantified as the percentage of control absorbance of reduced dye at 550 $\mathrm{nm}$ on microplate reader (LabtechLT-4000MS, Labtechm International Ltd., East Sussex, and UK). For each treatment, five replicate wells were examined, and each experiment was repeated three times $(n=3)$. Standard error of mean (SEM) was calculated between three experiments. The results were calculated as percentage growth inhibition, untreated (control) cells versus treated cells according to the following formula (Qadir, 2014):

$$
\% \text { Growth inhibition }=\frac{\text { Control }- \text { actual absorbance }}{\text { Control }} \times 100
$$

Absorbance of the media was subtracted both from control and treated cells.

\section{Neutral red uptake assay}

The neutral red assay is basically a metabolic impairment assay, which works simply on the principle that this dye accumulates in the lysosomes of viable cells by a combination of active endocytosis and pinocytosis until a stable equilibrium is reached. Alterations of the cell surface or the sensitive lysosomal membrane lead to lysosomal fragility and other changes that gradually become irreversible. Such changes produced by toxic substances cause decreased uptake and binding of neutral red, making it possible to distinguish between viable, healthy and damaged or dead cells. Metabolically inactive cells lose their ability to accumulate and retain neutral red dye (Borenfreund and Puerner, 1985). However, this loss does not occur until late in the apoptotic process, when membrane integrity is compromised.

The neutral red uptake assay was performed according to the method of (Borenfreund and Puerner, 1985) by removal of the medium after dosing cells and $200 \mu \mathrm{L}$ of neutral red solution $(40 \mu \mathrm{g} / \mathrm{mL})$ was added to each well (including the blanks, which contained medium only). After incubation for two and half hours, the neutral red was removed, cells were carefully rinsed with prewarmed PBS, and $200 \mu \mathrm{L}$ of ethanol/acetic acid $(1 \%$ glacial acetic acid in 5\% ethanol) was added to all wells.

The plates were covered in foil and placed on a plate shaker for $30 \mathrm{~min}$ to extract neutral red dye from the cells to form a homogeneous solution. Absorbance of the wells was measured at $540 \mathrm{~nm}$ in a microplate reader within $60 \mathrm{~min}$. For each treatment, five replicates wells were examined and each experiment was repeated three times $(n=3)$. The results were calculated as percentage growth inhibition, untreated (control) cells versus treated cells, according to the formula as described previously for MTT assay. Standard error means were calculated between three experiments.

\section{Cytomorphological alterations (DAPI staining)}

DAPI (4', 6-diamidino-2-phenylindole) is a DNAspecific probe, which forms a fluorescent complex by attaching in the minor groove of $\mathrm{A}-\mathrm{T}$ rich sequences of DNA. Binding of DAPI to DNA produces a $\sim 20$-fold fluorescence enhan-cement, apparently due to the displacement of water molecules from both DAPI and the minor groove (Kapuscinski, 1995). The bluefluorescent DAPI nucleic acid stain preferentially stains DNA and is used to study the morphological condition of cancer cells, espe-cially as a marker for apoptosis in the cells. DAPI produces a blue fluorescence when bound to DNA with excitation at about $360 \mathrm{~nm}$ and emission at $460 \mathrm{~nm}$.

In the present study, DAPI stain was used to assess the morphological changes in nuclei of control and treated cells. Cells were seeded at density of $1 \times 10^{4}$ cells/well in $500 \mu \mathrm{L}$ of medium on sterilized glass cover slips in well plates for 24 hours. Caco- 2 cells were treated with the negative control (culture medium), positive control (actinomycin-D, $4 \mu \mathrm{M}$ ). The plates were incubated at $37^{\circ} \mathrm{C}, 5 \% \mathrm{CO}_{2}$ in air in a humidified atmosphere for 24 hours. After treatment, cells were briefly equilibrated with PBS, fixed with $4 \%$ paraformaldehyde for $15 \mathrm{~min}$, permeabilised with methanol for $5 \mathrm{~min}$, and mounted in a DAPI-containing medium (Vector Shield, Vector Labs, Peterborough, UK). The morphology of the nuclei was observed using a confocal fluorescence microscope, Leica SP2 AOBS confocal microscope (Leica Microsystems, Mannheim, Germany) with excitation at 350 $\mathrm{nm}$ and emission $460 \mathrm{~nm}$ under a $\times 40$ oil objective.

\section{Data presentation and statistical analysis}

All data were compiled from a minimum of three experiments. Data for statistical analysis were expressed as the standard error mean, $n$ (number of experiments). One-way ANOVA with Dunnett's test, as specified, was performed using GraphPad Prism version 6.00 for Windows, GraphPad Software, San Diego California, USA.

\section{Results}

The present study was conducted to determine the ability of G. trichophylla crude extract and isolated saponins fraction against the proliferation of human colorectal cancer cells. Previous studies conducted showed that various isolated phytoconstituents provi- 


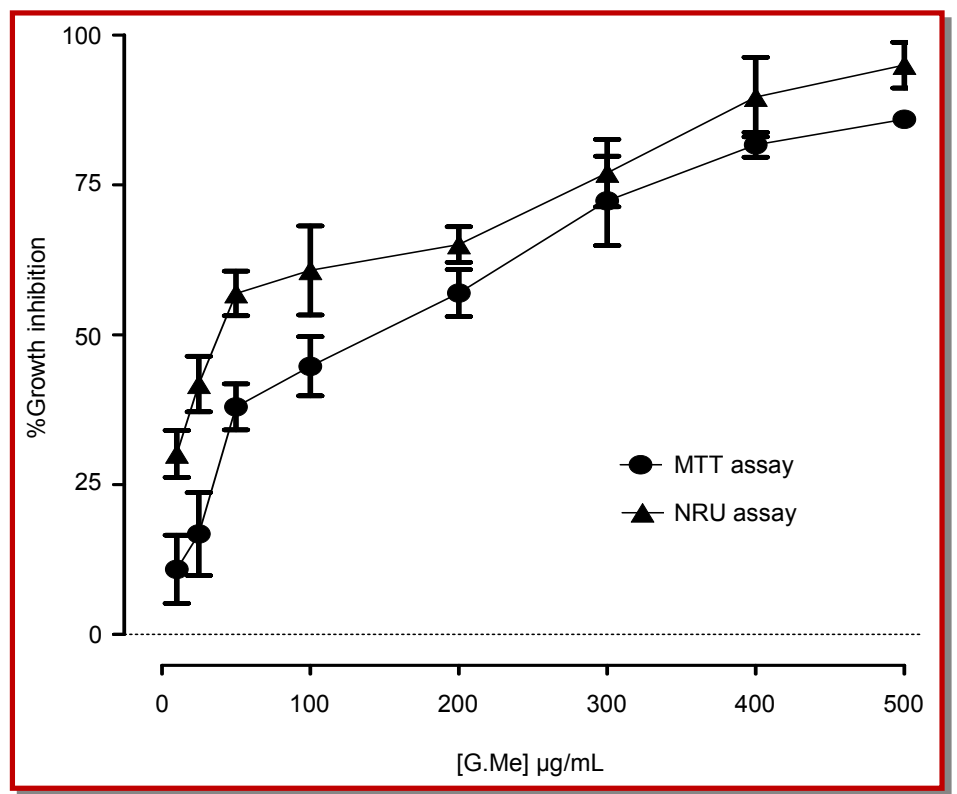

Figure 1: Dose-dependent growth inhibitory activity of G. trichophylla methanol extract (G.Me) against Caco-2 human cancer cells. The graph also provides a comparison between MTT and NRU assay sensitivities

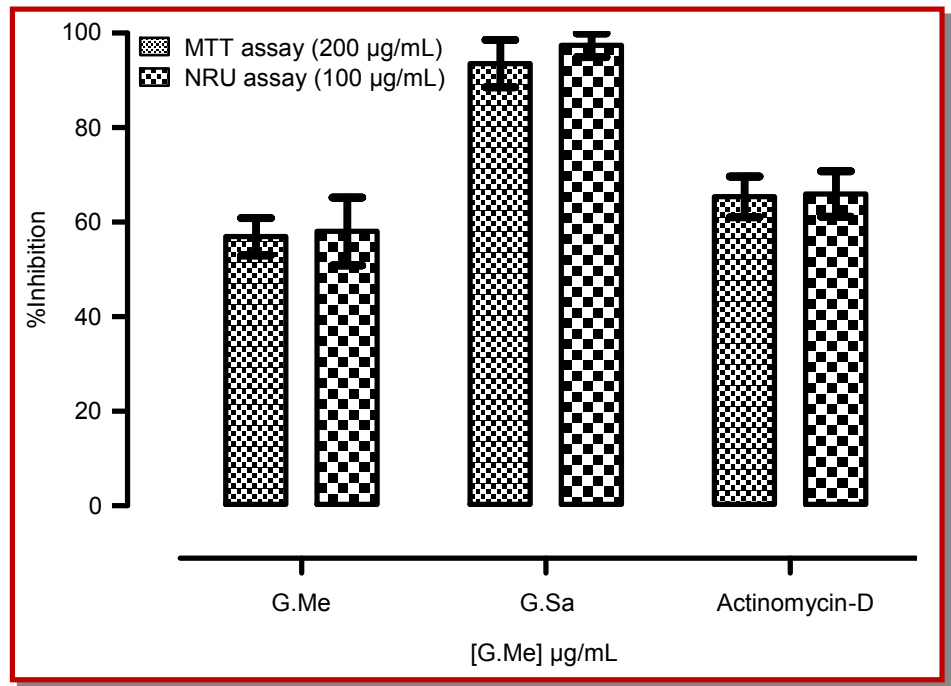

Figure 2: A comparison of G. trichophylla methanol and saponins extract and standard drug actinomycin D growth inhibitory activities against colorectal cancer cells (Caco-2). All the results are represented as mean \pm SEM $(n=3)$

ded a great potential for new strategies in exploring anticancer drugs (Brown and Attardi, 2005).

The crude methanol extract of G. trichophylla showed a dose dependent growth inhibition of Caco-2 cancer cells with an apparent IC $_{50}$ value of $200 \mu \mathrm{g} / \mathrm{mL}$ in MTT assay. The very high significance inhibition $(\mathrm{p}<0.001)$ of the growth was observed above the dose of $200 \mu \mathrm{g} / \mathrm{mL}$ (Figure 1). The effect of saponins extract against Caco-2 cancer cells was tested at dose of $200 \mu \mathrm{g} / \mathrm{mL}$ for MTT assays. The crude saponins showed maximum effect and inhibited the growth of Caco-2 by $93.6( \pm 5.0) \%$ with respect to $65.4( \pm 4.3) \%$ inhibition of actinomycin-

\section{$\mathrm{D}(4 \mu \mathrm{M})$.}

The methanol extract showed the dose dependent growth inhibition of the Caco- 2 cancer cell lines with apparent $\mathrm{IC}_{50}$ value of $100 \mu \mathrm{g} / \mathrm{mL}$ in NRU assay. The highly significance $(p<0.001)$ response was observed with a dose of $50 \mu \mathrm{g} / \mathrm{mL}$ and above (Figure 1). The saponins showed maximum effect and inhibited the growth of Caco-2 by $97.4( \pm 3.3) \%$ with respect to 66.0 ( \pm $4.8) \%$ inhibition of actinomycin-D $(4 \mu \mathrm{M})$ (Figure 2$)$.

The DAPI staining of crude saponins treated cells when observed under confocal microscope. The nuclei were shrunken and signs of marked nuclear fragmentation 

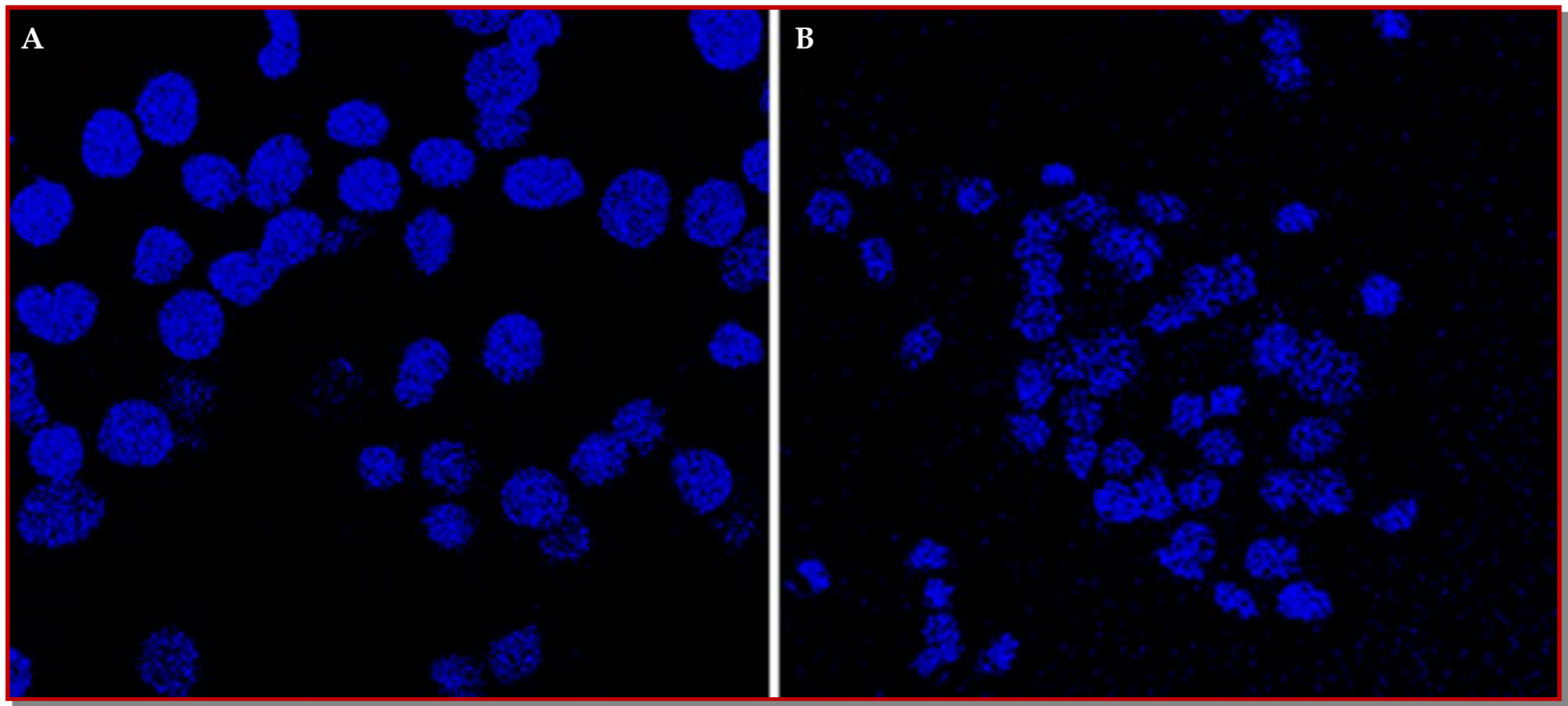

Figure 3: A) Control (untreated Caco-2 cells); B) Cells treated with G. trichophylla saponins (10 $\mu \mathrm{g} / \mathrm{mL}$, final concentration) for 24 hours and visualized under confocal microscope for DAPI stain

and chromatin condensation were observed. It was very clear that the numbers of apoptotic body fragments were more as compared to untreated cells (control) where nuclei is intact and there was no apparent signs of DNA fragmentation. Based on these observations we may suggest that Caco-2 cells, after treating with saponins fraction followed a programmed cell death pathway, an indication of the apoptosis mode of cell death, that is more obvious than necrosis (Figure 3).

\section{Discussion}

The plants belonging to genus Gaultheria have also been reported to inhibit the human lung, prostate and liver cancer cell lines (Chen et al., 2009; Li et al., 2010). It is reported that saponins exert its cytotoxic activity through apoptosis through signalling pathways to prevent the tumors (Han et al., 2013). DAPI staining is most commonly used assay for observing the apoptosis at DNA level (Saha et al., 2013). In this study, saponins extract induced morphological changes in apoptotic cells which were observed in DAPI staining. This demonstrates that the treatment with saponins extract resulted in apoptotic body formation, chromatin condensation and nuclear fragmentation. It clearly indicates the potential of saponins extract to induce apoptosis against colon cancer cell lines i.e. Caco-2.

In conclusion, the present study shows that G. trichophylla methanol extract and its saponins fractions possess dose dependent growth inhibitory and potentially an apoptotic pathway against the human colon carcinoma Caco-2 cells.

\section{References}

Alauddin M, Bryce $T$, Clayton E, Martin-Smith M, Subramanian G. Triterpenoids from New Zealand plants: Isolation of ursolic acid from Gaultheria subcorymbosa col. J Chem Soc. 1965: 4611-12.

Borenfreund E, Babich H, Martin-Alguacil N. Comparisons of two in vitro cytotoxicity assays: The neutral red (NR) and tetrazolium MTT tests. Toxicology in vitro. 1988; 2: 1-6.

Borenfreund E, Puerner JA. Toxicity determined in vitro by morphological alterations and neutral red absorption. Toxicol Lett. 1985; 24: 119-24.

Brown JM, Attardi LD. The role of apoptosis in cancer development and treatment response. Nature Rev Cancer. 2005; 5: 231-37.

Cambie R, Cain B, La Roche S. A New Zealand phytochemical survey-Part 2. The Dicolytedons NZJ Sci. 1961; 4: 604-63.

Chen CY, Lin RJ, Huang JC, Wu YH, Cheng MJ, Hung HC, et al. Chemical constituents from the whole plant of Gaultheria itoana Hayata. Chem Biodiversity. 2009; 6: 1737-43.

Cybulska P, Thakur SD, Foster BC, Scott IM, Leduc RI, Arnason JT, et al. Extracts of Canadian first nations medicinal plants, used as natural products, inhibit Neisseria gonorrhoeae isolates with different antibiotic resistance profiles. Sex Transm Dis. 2011;38:667-71.

Dande PR, Talekar VS, Chakraborthy G. Evaluation of crude saponins extract from leaves of Sesbania sesban (L.) Merr. for topical anti-inflammatory activity. Int J Res Pharm Sci. 2010; 1: 296-99.

El-Basyouni SZ, Chen D, Ibrahim R, Neish A, Towers G. The biosynthesis of hydroxybenzoic acids in higher plants. Phytochemistry 1964; 3: 485-92. 
Farnsworth NR, Soejarto D. Global importance of medicinal plants. In: Conservation of medicinal plants. 1991, pp 25-51.

Green DR, Kroemer G. The pathophysiology of mitochondrial cell death. Science 2004; 305: 626-29.

Grisebach H, Vollmer K. On the biosynthesis of benzoic acid in Gaultheria procumbens L. II. Zeitschrift fur Naturforschung Teil B: Chemie, Biochemie, Biophysik, Biologie. 1964; 19: 781 -83 .

Han L-T, Fang Y, Li M-M, Yang H-B, Huang F. The antitumor effects of triterpenoid saponins from the anemone flaccida and the underlying mechanism. J Evid Based Complementary Altern Med. 2013.

Huang TC. Editorial Committee of the flora of Taiwan. Department of Botany, National Taiwan University, Taiwan. 2003.

Ibrahim R, Towers G. The identification, by chromatography, of plant phenolic acids. Arch Biochem Biophys. 1960; 87: 125 -28 .

Kapuscinski J. DAPI: A DNA-specific fluorescent probe. Biotech Histochem. 1995; 70: 220-33.

Lau C, Ho C, Kim C, Leung K, Fung K, Tse T, et al. Cytotoxic activities of Coriolus versicolor (Yunzhi) extract on human leukemia and lymphoma cells by induction of apoptosis. Life Sci. 2004; 75: 797-808.

Li J, Li F, Lu Y-Y, Su X-J, Huang C-P, Lu X-W. A new dilactone from the seeds of Gaultheria yunnanensis. Fitoterapia 2010; 81: 35-37.

Liu W-R, Qiao W-L, Liu Z-Z, Wang X-H, Jiang R, Li S-Y, et al. Gaultheria: Phytochemical and pharmacological characteristics. Molecules 2013; 18: 12071-108.

MacDonald RS, Guo J, Copeland J, Browning JD, Sleper D, Rottinghaus GE, et al. Environmental influences on isoflavones and saponins in soybeans and their role in colon cancer. J Nutr. 2005; 135: 1239-42.

Royle JF. Illustrations of the botany and other branches of the natural history of the Himalayan Mountains and of the flora of Cashmere, Textband, Allen, 1839.
Saha SK, Sikdar S, Mukherjee A, Bhadra K, Boujedaini N, Khuda-Bukhsh AR. Ethanolic extract of the Goldenseal, Hydrastis canadensis, has demonstrable chemopreventive effects on HeLa cells in vitro: Drug-DNA interaction with calf thymus DNA as target. Environ Toxicol Pharmacol. 2013; 36: 202-14.

Siegel R, Naishadham D, Jemal A. Cancer statistics, 2013. CA: A Cancer J Clin. 2013; 63: 11-30.

Simon JE, Chadwick AF, Craker LE. Herbs, an indexed bibliography, 1971-1980. Elsevier, 1984.

Sylvester PW. Optimization of the tetrazolium dye (MTT) colorimetric assay for cellular growth and viability. Drug Design Disc. Springer, 2011, pp 157-68.

Twentyman P, Luscombe M. A study of some variables in a tetrazolium dye (MTT) based assay for cell growth and chemosensitivity. British J Cancer. 1987; 56: 279.

Wong R. Apoptosis in cancer: From pathogenesis to treatment. J Exp Clin Cancer Res. 2011; 30: 87.

Xiong Y, Xiao B, Ma X, Li C, Zheng J, Ye J. Effects of Gaultheria yunnanensis on adjuvant arthritis in rats. Zhongguo Zhong yao za zhi- Zhongguo zhongyao zazhi- China J Chinese Materia Medica. 2009; 34: 2516-19.

Zhang B, He X-L, Ding Y, Du G-H. Gaultherin, a natural salicylate derivative from Gaultheria yunnanensis: Towards a better non-steroidal anti-inflammatory drug. Eur J Pharmacol. 2006; 530: 166-71.

Zhang D, Liu R, Sun L, Huang C, Wang C, Zhang D-M, et al. Anti-inflammatory activity of methyl salicylate glycosides isolated from Gaultheria yunnanensis (Franch.) Rehder. Molecules 2011; 16: 3875-84.

Zhang Z, Guo D, Li C, Zheng J, Koike K, Jia Z, et al. Two diterpenoids from the roots of Gaultheria yunnanensis. J Nat Prod. 1999; 62: 297-98.

Zhang Z, Guoi D, Li C, Zheng J, Jia Z. Studies on the chemical constituents of Yunnan wintergreen root Gaultheria yunnanensis (II). Chinese Traditional Herbal Drugs. 1998; 30: 167-69. 


\section{Your feedback about this paper}

1. Number of times you have read this paper 0

2. Quality of paper Click

3. Your comments

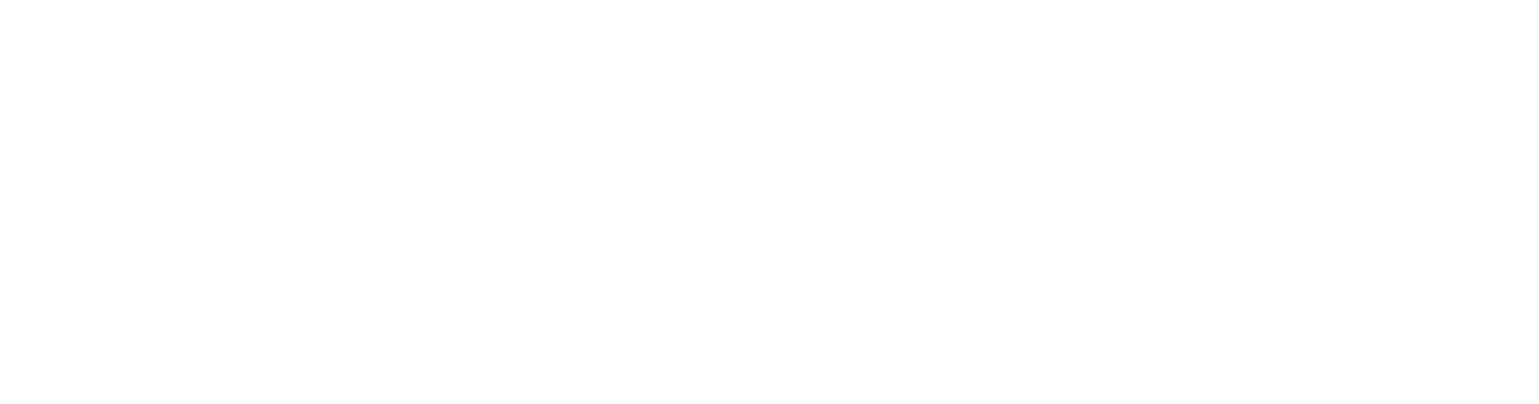

